\title{
GRAIN YIELD AND STABILITY OF THE NEW DURUM WHEAT CULTIVAR BANI SUEF 6
}

Sadek, Eman M. *; Moustafa, M.A.; M.S. Shrshar; T. Shehab El-Din; M. Abo Shereef; S. Abdel-Majeed; M. Abdel-Aleem; S. R. Sabry; A. Hamada; A. Abo-Warda; A. Tammam; M. Meshref; E.El-Sayed; H. Ashoush; M. Tawfelies; H. Hendawy; Hayam S. Mahgoub; A. K. Mostafa; H. El-Borham; A. Menshawy; A. Moussa; Wafaa M. ElAwady; R. Koumbor; S. Seleem; Nadia A. Abdel-Nour; G. Sharawy; S. Abdel-Dayem; Sohair M. Hassan; A. Swelam; S. El-Sawy; S. Hammad; Magda A. Abdel-Rahman; Sabah H. Abo Elela; M. A. Khaled; R. A. Ramadan; I. A. Amin; M. Zakaria; Manal A. Hassan; A. Gad-Allah; M. A .El-Maghraby; A. Morad; Aza M. Abdel-Al; A. Hagras; A. T. Mostafa; M. S. Mahmoud; M. Y. Mubark; Hoda M.M El-Gharbawy , A.A. Mahmoud, A. Gomaa; Enayat Ghanem; M. ElMonofy; S. kh. Mahmoud; N. Hanna; M. A. Moussa; M. A. Gouda; A. Ageez; M. A. Salem; A. Khattab; A. Abdel-Lattif; A. El-Hag ; Najwa Abdel-Fattah; F. Hefnawy; and ${ }^{* *}$ W. Abdel-Samad ${ }^{* *}$; M.A. Hassan $^{\star *}$; and E.A.Yossef **

* Wheat Res. Dept., Field Crops Res. Inst., ARC, Giza 12619, Egypt.

** Plant Pathology Res. Inst., Agric. Res. Center, Giza, Egypt.

\section{ABSTRACT}

The new promising durum wheat cultivar Bani Suef 6 was newly released from Wheat Research Department, Field Crops Research Institute, ARC, Egypt. Bani Suef6 has been selected from CIMMYT materials grown at Sids Agricultural Research Station. Yield evaluation was performed through 31 experiments conducted at different levels of preliminary and advanced yield trials during the three successive growing seasons from 2004/2005 to 2006/2007. The results revealed that the new durum wheat cultivar Bani Suef6 has high yielding ability compared with commercial durum wheat cultivars. Moreover, stability analysis for grain yield showed that Bani Suef 6 has better stability parameters in the three main regions for durum wheat cultivated in Egypt, i.e., Middle Egypt, Upper Egypt and Out Valley. Also, the results of rust diseases reactions cleared that Bani Suef 6 has high resistance to leaf and stem rust diseases. Studies on yield components of Bani Suef 6 revealed that the new cultivar had significantly surpassed the check durum cultivars in number of spikes $/ \mathrm{m}^{2}$, number of kernels/spike and higher 1000-kernel weight confirming the contribution of yield components in improving grain yield of the new durum cultivar Bani Suef 6. Studies on number of days to heading revealed that Bani Suef 6 recorded 98.7 days to heading which was earlier than some durum cultivars and almost equal to the average of all cultivars (99.1 days). Similarity, Bani Suef 6 was the earliest in physiological maturity (147.7 days) while other durum checks ranged from 149.0 to 150.8 with an average of 149.7 days. Bani Suef 6 recorded the lowest plant height $(101.0 \mathrm{~cm}$ vs. $106.0 \mathrm{~cm}$ for the average of other cultivars). Physical and chemical analyses of durum wheat grains showed that the new cultivar Bani Suef 6 had a higher score over the average of the other four durum cultivars in hectoliter (83.1 vs. $82)$, Semolina ( 77.0 vs. $76.6 \%$ ), protein (12.9 vs. $12.3 \%$ ), wet gluten (29.6 vs. $28.4 \%$ ) and dry gluten (10.8 vs. $10.0 \%)$. 


\section{INTRODUCTION}

Wheat is the most important cereal crop in Egypt since 7000 years. It is the basic staple food in urban areas. Also, it is mixed with maize flour in rural areas. Durum wheat provides semolina for pasta and macaroni industries. Elouafi et.al (1998) stated that durum wheat represents $80 \%$ of wheat area in Mediterranean basin. Durum Wheat grain is processed to different end products and the most known are pasta, couscous and borghul. The grain quality parameters for these products are generally known, particularly, the gluten strength. Peterson (1997), cleared the importance of regional trials to test wheat cultivars. Moreover, Bowman (1998), indicated that two year multi- location data would be useful to select wheat cultivars. Comparing yield potential of the newly released durum wheat cultivars with the commercial durum wheat cultivars on farmers' fields over number of years is of utmost importance to verify the on agricultural research station yield potential expectations of the new durum wheat promising lines. The results of these trials help the breeder to take the right decisions regarding the new cultural distribution among farmers and enhance the diffusion of those new cultivars among wheat growers. Abdel-Shafi et al. (1989) reported that both Sohag 2 and Bani Suef 1 were recommended for Middle Egypt. However, Mitkees et al. (1989), stated that, Sohag 1 was quite stable over both Middle and Upper Egypt due to its tolerance to high temperature in these regions. Ghanem, Enayat et al. (1991), noticed that, Sohag 3 outyielded Sohag 1 with about 6-13\%. However, Sadek,Eman et al. (1995), reported that, Bani Suef 1 produced the maximum grain yield when compared to commercial cultivars Sohag 1, Sohag 2 and Sohag 3. Ghanem, Enayat et al. (1996), found that, Bani Suef 3 mean grain yield was significantly the highest compared to the commercial durum wheat cultivars in Middle and Upper Egypt. Recently, Abdel - Aleem et al. (2008) found that, Bani Suef 4 proved its superiority in grain yield compared with the local commercial durum wheat cultivars. Moreover, Moustafa et al. (2008) proved the high yielding ability of Bani Suef 5 compared to the local durum wheat checks. The objective of this work is to assess grain yield and stability parameters for the new durum wheat cultivar Bani Suef 6 compared to the commercial durum wheat cultivars in the three agroclimatic zones of the old and new reclaimed areas of Egypt, i.e. Middle Egypt, Upper Egypt and Out Valley.

\section{MATERIALS AND METHODS}

The newly durum wheat cultivar Bani Suef 6 has been selected from CIMMYT materials grown at Sids Agricultural Research Station, ARC, in 2002/2003 season. The cross name and pedigree of the cultivar are BOOMER-21/BUSCA-3 and CDSS95Y001185-8Y-0M-0Y-0B-1Y-0B-0SD.

Afterwards, Bani Suef 6 was advanced to Sids durum wheat screening nurseries in 2003/2004 season. Bani Suef 6 was tested in seven preliminary yield trials in 2004/2005 season. In the next season, it was transferred to the advanced yield trials, 24 advanced yield trials were conducted at Middle 
Egypt, Upper Egypt and Out Valley for the two successive seasons 2005/2006 and 2006/2007 with the commercial durum wheat cultivars. The experimental plot area was 6 rows, $4 \mathrm{~m}$ long and $20 \mathrm{~cm}$ apart $(4.8 \mathrm{~m} 2)$ for the screening in the preliminary yield trials. Meanwhile, it was $10.5 \mathrm{~m} 2$ for the advanced yield trials. The Randomized Complete Block Design (RCBD) was used according to Steel and Torrie (1980) in both preliminary and advanced yield trials. Moreover, stability parameters for grain yield of the advanced yield trials were calculated according to Eberhart and Russell (1966). Yield components, i.e., number of spikes $/ \mathrm{m}^{2}$, number of kernels/spike and 1000 kernel weight, were recorded as number of fertile spikes per square meter, within guarded plants, number of kernels per spike as average of ten spikes selected randomly and 1000-kernel weight as the weight of 1000 kernels counted randomly after harvesting. Days to heading was taken at the emergence of $50 \%$ of the full spike from each plot, number of days to physiological maturity was recorded when $50 \%$ of the most upper internodes (peduncle) turned yellow. Plant height was measured as the distance from soil surface to the upper part of the main spike excluding awns (average of ten measurements).

\section{RESULTS AND DISCUSSION}

\section{1- Preliminary Yield Trials:}

The results in Table (1) illustrated grain yield ( $\mathrm{ard} / \mathrm{fad})$ of the preliminary yield trials for Bani Suef 6 and five durum wheat commercial cultivars in 2004/2005 season. The newly durum wheat cultivar Bani Suef 6 had significantly overcome the check mean at Sids location and in the over all mean of the tested locations. These results agreed with those obtained by Abdel-Shafi et al. (1989) concerning Bani Suef 1. However, at the rest of preliminary yield trials there was insignificant difference in grain yield of Bani Suef 6 and the check mean.

\section{2- Advanced Yield Trials:}

Data in Table (2 a) show the grain yield ( $\mathrm{ard} / \mathrm{fad})$ of the advanced yield trials for Bani Suef 6 and three durum wheat cultivars in Middle Egypt in 2005/2006 season. Bani Suef 6 significantly surpassed the check mean at Sids, Mallawy and in the over all mean of the Middle Egypt. These results proved the high yielding ability of durum wheat cultivar Bani Suef 6 and its adaptability for Middle Egypt region and confirm with those obtained by Peterson (1997) and Abdel-Shafie et al. (1989).

For the results of Upper Egypt region in 2005/2006 (Table 2b), data show that the newly durum wheat cultivar had significantly overcome the check mean at shandaweel location and in the over all mean of Upper Egypt region. 
Table (1): Grain Yield (ard / fad ) of the preliminary yield trials for Bani Suef 6 and five durum wheat cultivars in 2004/2005 season.

\begin{tabular}{|c|c|c|c|c|c|c|c|c|}
\hline \multirow{2}{*}{ Cultivar } & \multicolumn{7}{|c|}{ Locations } & Mean \\
\cline { 2 - 8 } & Sids & Mallawy & Assuit & $\begin{array}{c}\text { Shand- } \\
\text { aweel }\end{array}$ & Matanaa & $\begin{array}{c}\text { Kom } \\
\text { Ombo }\end{array}$ & $\begin{array}{c}\text { New } \\
\text { Valley }\end{array}$ & \\
\hline Bani Suef 1 & 25.38 & 28.60 & 13.45 & 21.77 & 16.72 & 24.07 & 12.32 & 20.33 \\
Bani Suef 3 & 23.52 & 23.84 & 16.84 & 25.51 & 19.52 & 22.55 & 15.14 & 20.99 \\
Bani Suef 4 & 21.88 & 27.85 & 19.25 & 21.99 & 24.97 & 20.57 & 15.95 & 21.78 \\
Bani Suef 5 & 21.55 & 24.94 & 23.30 & 21.72 & 24.36 & 20.69 & 13.15 & 21.39 \\
Sohag 3 & 24.28 & 24.66 & 16.19 & 20.30 & 21.59 & 18.90 & 10.27 & 19.46 \\
Check Mean & 23.32 & 25.98 & 17.81 & 22.26 & 21.43 & 21.36 & 13.37 & 20.79 \\
Bani Suef 6 & $28.55^{\star}$ & 27.73 & 16.19 & 25.05 & 24.41 & 23.34 & 14.76 & $22.86^{*}$ \\
\hline Mean & 23.62 & 25.46 & 15.48 & 22.49 & 21.52 & 22.70 & 11.85 & 20.45 \\
\hline L.S.D. 5\% & 4.20 & 3.20 & 2.34 & 3.56 & 6.32 & 3.97 & 2.51 & 1.47 \\
CV \% & 12.71 & 8.96 & 10.79 & 11.31 & 20.97 & 12.48 & 15.11 & 13.72 \\
\hline
\end{tabular}

Table ( 2a ) : Grain Yield (ard / fad ) of the advanced yield trials for Bani Suef 6 and three durum wheat cultivars in Middle Egypt in 2005/2006 Season.

\begin{tabular}{|c|c|c|c|c|}
\hline \multirow{2}{*}{ Cultivar } & \multicolumn{3}{|c|}{ Locations } & \multirow{2}{*}{ Mean } \\
\cline { 2 - 3 } & Sids & Mallawy & El-Minia & \\
\hline Bani Suef 3 & 26.84 & 21.86 & 20.14 & 22.95 \\
Bani Suef 4 & 27.14 & 23.28 & 17.37 & 22.60 \\
Sohag 3 & 26.33 & 22.35 & 20.87 & 23.18 \\
Check Mean & 26.77 & 22.50 & 19.46 & 22.91 \\
Bani Suef 6 & $30.14^{*}$ & $25.11^{*}$ & 19.47 & $24.91^{*}$ \\
\hline Mean & 27.10 & 22.44 & 19.01 & 22.85 \\
\hline LSD .5\% & 2.52 & 1.69 & 1.42 & 1.09 \\
CV\% & 6.51 & 5.26 & 5.24 & 5.93 \\
\hline
\end{tabular}

While, at Matanaa, Sohag and Kom Ombo locations there was insignificant differences between the new durum wheat cultivar Bani Suef 6 and the check mean. These results revealed the high yielding ability and adaptability for the new durum wheat cultivar Bani Suef 6 for Upper Egypt region and agreed with that obtained by Mitkees et al. (1989).

The results of advanced yield trials in Out Valley in 2005/2006 season (table 2c) cleared that the new durum wheat cultivar Bani Suef 6 had significantly outyielded the check mean at Assuit, Aswan, New Valley locations and in the over all mean of the Out Valley region. These results revealed the superiority of Bani Suef 6 and its adaptability for Out Valley region and agreed with those obtained by Abdel-Aleem et al. (2008).

For advanced yield trials in Middle Egypt in 2006/2007 season (Table 3a), the new durum wheat cultivar Bani Suef 6 had significantly overcome the check mean in grain yield at Sids, Mallawy, El-Menia and in the over all mean of Middle Egypt region. The results cleared the high yielding ability for the durum wheat cultivar Bani Suef 6 and its high adaptability for Middle Egypt region and confirm with those obtained by Bowman (1998), Ghanem, Enayat et al. (1991) and Sadek, Eman et al. (1995).

Table (3b) shows the grain yield (ard/fad) of the advanced yield trials for the durum wheat cultivar Bani Suef 6 and five durum wheat cultivars (checks), i.e. Bani Suef 1,3,4,5 and Sohag3 in Upper Egypt in 2006/2007 
season. The durum wheat cultivar Bani Suef 6 had significantly outyielded the check mean at Shandaweel location and in the over all mean of Upper Egypt region.

Table (2b): Grain Yield (ard/fad) of the advanced yield trials for Bani Suef 6 and three durum wheat cultivars in Upper Egypt in 2005/2006 season.

\begin{tabular}{|l|c|c|c|c|c|}
\hline \multirow{2}{*}{ Cultivar } & \multicolumn{4}{|c|}{ Locations } & \multirow{2}{*}{ Mean } \\
\cline { 2 - 5 } & Shandaweel & Matanaa & Sohag & Kom Ombo & \\
\hline Bani Suef 3 & 30.34 & 28.00 & 24.07 & 22.19 & 26.15 \\
Bani Suef 4 & 25.98 & 26.74 & 23.94 & 23.86 & 25.13 \\
Sohag 3 & 26.81 & 24.87 & 25.87 & 22.81 & 25.09 \\
Check Mean & 27.71 & 26.54 & 24.63 & 22.95 & 25.46 \\
Bani Suef 6 & $31.85^{*}$ & 28.34 & 25.94 & 25.73 & $27.96^{\star}$ \\
\hline \multicolumn{1}{|c|}{ Mean } & 28.03 & 25.54 & 24.38 & 23.17 & 25.28 \\
\hline LSD .5\% & 2.63 & 3.34 & 2.62 & 2.81 & 1.39 \\
CV \% & 6.50 & 9.14 & 7.53 & 8.50 & 7.91 \\
\hline
\end{tabular}

Table (2c): Grain Yield (ard/fad) of the advanced yield trials for Bani Suef 6 and three durum wheat cultivars in Out Valley in 2005/2006 season.

\begin{tabular}{|l|c|c|c|c|c|}
\hline \multirow{2}{*}{ Cultivar } & \multicolumn{3}{|c|}{ Locations } & \multirow{2}{*}{ Mean } \\
\cline { 2 - 5 } & Assuit & Aswan & New Valley & Toshkey & \\
\hline Bani Suef 3 & 9.60 & 21.14 & 17.64 & 12.01 & 15.10 \\
Bani Suef 4 & 10.70 & 14.47 & 16.30 & 11.23 & 13.18 \\
Sohag 3 & 11.57 & 15.67 & 13.67 & 11.59 & 13.12 \\
Check Mean & 10.62 & 17.09 & 15.87 & 11.61 & 13.80 \\
Bani Suef 6 & $12.97^{*}$ & $19.20^{*}$ & $18.14^{*}$ & 10.48 & $15.20^{*}$ \\
\hline Mean & 10.93 & 17.81 & 16.89 & 10.50 & 14.03 \\
\hline LSD . 5\% & 1.99 & 1.22 & 0.94 & 1.41 & 1.10 \\
CV \% & 12.74 & 11.53 & 9.37 & 11.26 & 11.30 \\
\hline
\end{tabular}

Table (3a): Grain Yield (ard/fad) of the advanced yield trials for Bani Suef 6 and five durum wheat cultivars in Upper Middle Egypt in 2006/2007 season.

\begin{tabular}{|l|c|c|c|c|c|}
\hline \multirow{2}{*}{ Cultivar } & \multicolumn{4}{c|}{ Locations } & \multirow{2}{*}{ Mean } \\
\cline { 2 - 5 } & Sids & Bani Suef & Mallawy & El-Menia & \\
\hline Bani Suef 1 & 28.27 & 26.25 & 20.41 & 18.20 & 23.28 \\
Bani Suef 3 & 28.80 & 23.80 & 21.67 & 21.35 & 23.91 \\
Bani Suef 4 & 29.57 & 24.85 & 23.30 & 22.05 & 24.94 \\
Bani Suef 5 & 30.60 & 25.55 & 24.29 & 25.38 & 26.46 \\
Sohag 3 & 28.40 & 24.85 & 20.27 & 23.45 & 24.24 \\
Check Mean & 29.13 & 25.06 & 21.99 & 22.09 & 24.57 \\
Bani Suef 6 & $31.20^{*}$ & 25.20 & $24.75^{\star}$ & $26.60^{*}$ & $26.94^{*}$ \\
\hline Mean & 29.34 & 24.72 & 22.35 & 22.75 & 24.79 \\
\hline LSD . 5\% & 1.43 & -- & 2.63 & 2.34 & 1.16 \\
CV \% & 3.41 & 8.02 & 8.27 & 7.21 & 6.70 \\
\hline
\end{tabular}

However, there was insignificant differences between Bani Suef 6 and check mean at the other locations in Upper Egypt region.

The results of the advanced yield trials in Out Valley in 2006/2007 season (Table 3c) revealed that the newly durum wheat cultivar Bani Suef 6 had significantly surpassed the check mean at New Valley, Assuit, Eoinaat 
and in the over all mean of Out Valley region. These results proved the superiority and high yielding ability for the durum wheat cultivar Bani Suef 6 compared to the commercial durum wheat cultivars and agreed with those obtained by Abdel Aleem et al. (2008) and Moustafa et al. (2008).

Table (3b): Grain Yield (ard/fad) of the advanced yield trials for Bani Suef 6 and five durum wheat cultivars in Upper Egypt in 2006/2007 season.

\begin{tabular}{|l|c|c|c|c|c|c|}
\hline \multirow{2}{*}{ Cultivar } & \multicolumn{5}{|c|}{ Locations } & \multirow{2}{*}{ Mean } \\
\cline { 2 - 6 } & Assuit & Shandaweel & Mattana & Sohag & $\begin{array}{c}\text { Kom } \\
\text { Ombo }\end{array}$ & \\
\hline Bani Suef 1 & 17.67 & 23.62 & 26.94 & 24.54 & 23.07 & 23.17 \\
Bani Suef 3 & 17.34 & 20.75 & 25.47 & 22.40 & 17.20 & 20.63 \\
Bani Suef 4 & 15.00 & 24.55 & 26.00 & 23.60 & 21.04 & 22.04 \\
Bani Suef 5 & 19.07 & 23.57 & 27.67 & 24.60 & 19.85 & 22.95 \\
Sohag 3 & 23.07 & 23.90 & 24.54 & 22.07 & 23.44 & 23.40 \\
Check Mean & 18.43 & 23.27 & 26.12 & 23.44 & 20.92 & 22.44 \\
Bani Suef 6 & 20.34 & $28.92^{*}$ & 29.07 & 23.14 & 21.55 & $24.60^{*}$ \\
\hline Mean & 20.84 & 24.38 & 27.01 & 23.97 & 21.22 & 23.49 \\
\hline LSD . 5\% & 3.27 & 3.42 & -- & 2.02 & 2.91 & 1.36 \\
CV \% & 11.02 & 9.80 & 9.51 & 5.90 & 9.61 & 9.28 \\
\hline
\end{tabular}

Table (3c): Grain Yield (ard/fad) of the advanced yield trials for Bani Suef 6 and five durum wheat cultivars in Out Valley in 2006/2007 season.

\begin{tabular}{|l|c|c|c|c|c|}
\hline \multirow{2}{*}{\multicolumn{1}{|c|}{ Cultivar }} & \multicolumn{4}{c|}{ Locations } & \multirow{2}{*}{ Mean } \\
\cline { 2 - 5 } & Nubaria & New Valley & Assuit & Eoinaat & \\
\hline Bani Suef 1 & 19.56 & 19.04 & 10.00 & 14.70 & 15.83 \\
Bani Suef 3 & 20.74 & 15.77 & 11.00 & 12.90 & 15.10 \\
Bani Suef 4 & 21.08 & 15.50 & 10.34 & 14.27 & 15.30 \\
Bani Suef 5 & 23.55 & 15.20 & 12.67 & 14.09 & 16.38 \\
Sohag 3 & 21.23 & 18.64 & 12.47 & 14.30 & 16.66 \\
Check Mean & 21.23 & 16.83 & 11.30 & 14.05 & 15.85 \\
Bani Suef 6 & 22.38 & $18.64^{*}$ & $13.34^{\star}$ & $16.67^{\star}$ & $17.76^{*}$ \\
\hline Mean & 20.88 & 16.96 & 11.79 & 14.68 & 16.08 \\
\hline LSD . 5\% & -- & 1.50 & 1.54 & 1.91 & 1.07 \\
CV \% & 11.03 & 6.28 & 9.14 & 9.11 & 9.53 \\
\hline
\end{tabular}

Table (4): Grain yield (Ard/Fad) of five durum wheat cultivars in six governorates in Upper and Middle Egypt in 2009/2010 season

\begin{tabular}{|c|c|c|c|c|c|c|c|c|c|}
\hline \multirow[b]{2}{*}{ No. } & \multirow[b]{2}{*}{ Cultivar } & \multicolumn{3}{|c|}{ Middle Egypt } & \multirow[b]{2}{*}{ Mean } & \multicolumn{3}{|c|}{ Upper Egypt } & \multirow[b]{2}{*}{ Mean } \\
\hline & & Fayoum & $\begin{array}{l}\text { Bani } \\
\text { Suef }\end{array}$ & El-Menia & & Assiut & Sohag & Aswan & \\
\hline 1 & Bani Suef 1 & 29.96 & 18.48 & 22.96 & 23.80 & 17.60 & 16.80 & 14.70 & 16.07 \\
\hline 2 & Bani Suef 3 & 26.04 & 18.60 & 18.20 & 20.95 & 19.30 & 18.48 & 12.40 & 16.73 \\
\hline 3 & Bani Suef 4 & 25.34 & 17.27 & 19.60 & 20.74 & 17.50 & 22.68 & 12.21 & 17.46 \\
\hline 4 & Bani Suef 5 & 25.83 & 17.64 & 19.88 & 21.12 & 17.80 & 21.84 & 13.22 & 17.62 \\
\hline 5 & Bani Suef 6 & 26.32 & 18.48 & 20.16 & 21.65 & 18.50 & 19.32 & 14.31 & 17.38 \\
\hline \multicolumn{2}{|c|}{$\begin{array}{l}\text { Governorate } \\
\text { Mean }\end{array}$} & 26.70 & 18.09 & 20.16 & 21.65 & 18.14 & 19.82 & 13.37 & 17.11 \\
\hline \multicolumn{2}{|c|}{ Region Means } & \multicolumn{4}{|c|}{21.65} & \multicolumn{4}{|c|}{17.11} \\
\hline \multicolumn{2}{|c|}{ Grand Mean } & \multicolumn{8}{|c|}{19.38} \\
\hline
\end{tabular}


Grain yield of Bani Suef 6 compared to other four durum wheat cultivars recorded from on-farm trail in six governorates in Middle and Upper Egypt are presented in Table 4. Grain yield of Bani Suef6 (21.65 Ard/fad) was higher than Bani Suef 3,4 , and 5 (20.95, 20.74 and $21.12 \mathrm{Ard} / \mathrm{fad}$, respectively) in Middle Egypt. In Upper Egypt, Bani Suef 6 grain yield (17.38 Ard/fad) was higher than that of Bani Suef1 and Bani Suef3 (16.07 and 16.73 Ard/fad). Bani Suef 6 had also recorded higher grain yield over Upper Egypt average (17.38 vs. $17.11 \mathrm{Ard} / \mathrm{fad}$ ). In general, grain yield of all durum cultivars was higher in Middle Egypt than that in Upper Egypt ( 21.65 vs. 17.11 Ard/fad).

\section{3- Stability Parameters for Grain Yield:}

Stability parameters for grain yield of the advanced yield trials in 2005/2006 season were calculated according to Eberhart and Russell (1966). The stable cultivar according to this method was defined as one which had a high average performance over a wide range of environments, a regression coefficient of 1.0 and no deviation from regression mean square. The results in (Table 5) proved that the newly durum wheat cultivar Bani Suef 6 has better stability parameters in the three main regions for durum wheat cultivated in Egypt, i.e. Middle Egypt, Upper Egypt and Out Valley and could be recommended for planting in those regions. These results confirm those obtained by Abdel- Shafi et al. (1989), Mitkees et al. (1989), Ghanem, Enayat et al. (1991) and Ghanem, Enayat et al. (1996).

Table (5): Grain Yield Stability Parameters for Bani Suef 6 as Compared with Local Checks in 2005/2006 Season.

\begin{tabular}{|c|c|c|c|}
\hline \multirow[b]{2}{*}{ Region / Cultivar } & \multirow{2}{*}{$\begin{array}{c}\text { Grain Yield } \\
\text { (ard/fad) }\end{array}$} & \multicolumn{2}{|c|}{ Stability Parameters } \\
\hline & & B & $\mathrm{S}_{\mathrm{d}}^{2}$ \\
\hline \multicolumn{4}{|l|}{ Middle Egypt: } \\
\hline Bani Suef 3 & 22.95 & 0.84 & 0.37 \\
\hline Bani Suef 4 & 22.60 & 1.19 & $1.61^{*}$ \\
\hline Sohag 3 & 23.18 & 0.69 & 0.00 \\
\hline Check Mean & 22.91 & -- & \\
\hline Bani Suef 6 & $24.91^{*}$ & 1.31 & 0.37 \\
\hline LSD $5 \%$ & 1.09 & & \\
\hline \multicolumn{4}{|l|}{ Upper Egypt: } \\
\hline Bani Suef 3 & 26.15 & 1.72 & 0.32 \\
\hline Bani Suef 4 & 25.13 & 0.50 & 0.52 \\
\hline Sohag 3 & 25.09 & 0.68 & 0.41 \\
\hline Check Mean & 25.46 & & \\
\hline Bani Suef 6 & $27.96^{*}$ & 1.34 & -0.47 \\
\hline LSD $5 \%$ & 1.39 & & \\
\hline \multicolumn{4}{|l|}{ Out Valley: } \\
\hline Bani Suef 3 & 15.10 & 1.30 & $2.90^{* *}$ \\
\hline Bani Suef 4 & 13.18 & 0.64 & 1.01 \\
\hline Sohag 3 & 13.12 & $0.48^{*}$ & -0.01 \\
\hline Check Mean & 13.80 & & \\
\hline Bani Suef 6 & $15.20^{*}$ & 1.06 & 0.41 \\
\hline LSD 5\% & 1.10 & & \\
\hline
\end{tabular}

\section{4- Yield Components:}

Data of yield components were collected from two-year advanced yield trials in Sids Research Station (representing Middle Egypt) and Shandaweel 
Research Station (representing Upper Egypt). Analysis of variance of yield components is presented in (Table 5) and showed that while mean squares for number of spikes $/ \mathrm{m}^{2}$ were insignificant for location, both number of kernels/spike and 1000-kernel were highly significant and significant, respectively, for locations effect. However, mean squares of cultivars were highly significant for number of spikes $/ \mathrm{m}^{2}$ while insignificant for the other two components. Seasons had high significant effect on number of spikes $/ \mathrm{m}^{2}$ but were insignificant for number of kernels/spike. Both types of interactions (LxC and LxS) were significant for number of spikes $/ \mathrm{m}^{2}$ while insignificant for the other two components (Table 6). Interactions between cultivars and season (CXS) were insignificant for the three yield components.

Performance of yield components are presented in (Table 7). Means of number of spikes $/ \mathrm{m}^{2}$ for Bani Suef 6 and other cultivar checks revealed that the new cultivar Bani Suef 6 had significantly surpassed the check cultivars in number of spikes $/ \mathrm{m}^{2}$. Similarly, Bani Suef 6 had a higher number of kernels/spike and higher 1000-kernel weight over the mean of check cultivars. These results confirm the superiority of the new cultivar in grain yield over the other check cultivars (Bani Suef 1, 3, 4, 5 and Sohag 3).

Table (6): Mean squares of the analysis of variance for number of spikes/m2, number of kernels/spike, 1000-kernel weight, number of days to heading, number of days to maturity and plant height

\begin{tabular}{|l|c|c|c|c|c|c|c|c|}
\hline \multicolumn{1}{|c|}{ S.O.V } & d.f & $\begin{array}{c}\text { No. of } \\
\text { spikes/m }\end{array}$ & $\begin{array}{c}\text { No. of } \\
\text { kernels/ } \\
\text { spike }\end{array}$ & $\begin{array}{c}\mathbf{1 0 0 0 -} \\
\text { kernel } \\
\text { weight }\end{array}$ & d.f & $\begin{array}{c}\text { Days to } \\
\text { heading }\end{array}$ & $\begin{array}{c}\text { Days to } \\
\text { maturity }\end{array}$ & $\begin{array}{c}\text { Plant } \\
\text { height }\end{array}$ \\
\hline Locations (L) & 1 & 793.5 & $971.2^{\star *}$ & $43.3^{*}$ & 1 & $542.5^{\star *}$ & $872.7^{\star *}$ & $782.9^{\star *}$ \\
\hline Cultivars (C) & 5 & $2889.1^{* *}$ & 36.1 & 19.3 & 5 & $18.09^{\star *}$ & 6.52 & $34.4^{\star *}$ \\
\hline Seasons (S) & 1 & $33152.7^{\star *}$ & 0.91 & $40.5^{*}$ & 2 & $109.1^{\star *}$ & $71.7^{\star *}$ & 14.93 \\
\hline L X C & 5 & $1532.2^{*}$ & 13.3 & 5.4 & 5 & 1.93 & 1.75 & 4.55 \\
\hline L X S & 1 & $1536.0^{*}$ & 32.3 & 20.5 & 2 & $36.3^{\star *}$ & 10.76 & 3.34 \\
\hline C X S & 5 & 927.5 & 6.3 & 11.6 & 10 & 1.75 & 4.47 & 10.37 \\
\hline & & & & & & & & \\
\hline C.V & & 3.7 & 9.52 & 4.6 & & 0.8 & 1.22 & 2.6 \\
\hline Grand mean & & 431.6 & 56.5 & 55.4 & & 99.02 & 149.4 & 105.15 \\
\hline
\end{tabular}

The performance of Bani Suef 6 and check cultivars at Middle and Upper Egypt (Table 8) confirm the data of the average performance all over Egypt for yield components. Data in (Table 8) show that the mean of check cultivars for number of spikes $/ \mathrm{m}^{2}$ in Middle Egypt was higher than that in Upper Egypt (435.3 vs. 416.4). At the same time number of spikes $/ \mathrm{m}^{2}$ for Bani Suef 6 was significantly higher than that for check cultivars in Upper Egypt while in Middle Egypt recorded insignificantly higher number of spikes $/ \mathrm{m}^{2}$. Increases in this trait may be the main component in detecting higher grain yield for the new durum cultivar all over Egypt.

Number of kernels/spike in Middle Egypt was higher than that in Upper Egypt for the mean of check cultivars (62.54 vs. 49.15) and for the new durum cultivar Bani Suef 6 (64.77 vs 55.38). The new durum wheat cultivar Bani Suef 6 detected higher number of kernels/spike in Middle Egypt than the mean of check cultivars (64.77 vs. 62.54) and similarity in Upper Egypt (55.38 
vs. 49.15). However, differences in number of kernels/spike between Bani Suef 6 and mean of check cultivars were insignificant in both Middle and Upper Egypt (Table 8). Data of 1000-kernel weight for the new durum cultivar Bani Suef 6 and other check cultivars in Middle and Upper Egypt are presented in (Table 8). Kernel weight in Middle Egypt was higher insignificantly than that in Upper Egypt for the mean of check cultivars (56.08 vs. 53.38) and for the new durum cultivar Bani Suef 6 (59.95 vs. 57.38). Simultaneously, 1000-kernel weight of Bani Suef 6 was higher than the mean of check cultivars in both Middle and Upper Egypt (Table 8).

Table (7): Means of number of spikes/m2, number of kernels/spike, 1000 -kernel weight, number of days to heading, number of days to maturity and plant height as affected by wheat cultivars over locations and seasons

\begin{tabular}{|l|c|c|c|c|c|c|}
\hline Cultivars & $\begin{array}{c}\text { No. of } \\
\text { spikes/m² }\end{array}$ & $\begin{array}{c}\text { No. of } \\
\text { kernels/ } \\
\text { spike }\end{array}$ & $\begin{array}{c}\text { 1000- } \\
\text { kernel } \\
\text { weight }\end{array}$ & $\begin{array}{c}\text { Days to } \\
\text { heading }\end{array}$ & $\begin{array}{c}\text { Days to } \\
\text { maturity }\end{array}$ & $\begin{array}{c}\text { Plant } \\
\text { height }\end{array}$ \\
\hline Bani Suef 1 & 395.5 & 52.9 & 57.1 & 96.3 & 149.0 & 104.9 \\
\hline Bani Suef 3 & 410.1 & 52.9 & 53.3 & 101.3 & 149.8 & 106.8 \\
\hline Bani Suef 4 & 457.9 & 58.3 & 55.8 & 99.4 & 149.2 & 106.6 \\
\hline Bani Suef 5 & 419.5 & 56.9 & 53.3 & 98.1 & 150.8 & 107.5 \\
\hline Sohag 3 & 446.0 & 58.2 & 54.3 & 100.3 & 149.7 & 104.1 \\
\hline Means & 425.8 & 55.8 & 54.8 & 99.1 & 149.7 & 106.0 \\
\hline Bani Suef 6 & 460.3 & 60.1 & 58.7 & 98.7 & 147.7 & 101.0 \\
\hline Grand Mean & 431.6 & 56.5 & 55.4 & 99.0 & 149.4 & 105.2 \\
\hline C.V & 3.7 & 9.5 & 4.6 & 0.8 & 1.2 & 2.6 \\
\hline LSD0.05 & 29.3 & 9.8 & 4.6 & 1.01 & 2.4 & 3.5 \\
\hline
\end{tabular}

Table (8): Means of number of spikes/m2, number of kernels/spike, 1000-kernel weight, number of days to heading, number of days to maturity and plant height as affected by locations and wheat cultivars over seasons.

\begin{tabular}{|c|c|c|c|c|c|c|c|}
\hline Locations & Cultivars & $\begin{array}{c}\text { No. of } \\
\text { spikes/m² }\end{array}$ & \begin{tabular}{|c|} 
No. of \\
kernels/ \\
spike
\end{tabular} & $\begin{array}{c}\text { 1000- } \\
\text { kernel } \\
\text { weight }\end{array}$ & $\begin{array}{l}\text { Days to } \\
\text { heading }\end{array}$ & $\begin{array}{l}\text { Days to } \\
\text { maturity }\end{array}$ & $\begin{array}{c}\text { Plant } \\
\text { height }\end{array}$ \\
\hline \multirow[t]{5}{*}{ Middle Egypt } & Bani Suef 1 & 430.5 & 59.53 & 58.36 & 100.25 & 154.58 & 110.63 \\
\hline & Bani Suef 3 & 431.3 & 57.76 & 54.56 & 105.08 & 153.91 & 110.00 \\
\hline & Bani Suef 4 & 449.8 & 63.40 & 57.37 & 102.92 & 154.25 & 110.75 \\
\hline & Bani Suef 5 & 430.0 & 66.14 & 52.72 & 103.00 & 155.50 & 112.50 \\
\hline & Sohag 3 & 435.0 & 65.91 & 57.42 & 103.50 & 154.33 & 108.75 \\
\hline \multicolumn{2}{|c|}{ Mean } & 435.3 & 62.54 & 56.08 & 102.95 & 154.51 & 110.53 \\
\hline \multicolumn{2}{|c|}{ Bani Suef 6} & 447.5 & 64.77 & 59.95 & 102.67 & 153.17 & 106.25 \\
\hline \multicolumn{2}{|c|}{\begin{tabular}{|l|l|} 
Upper Egypt & Bani Suef 1
\end{tabular}} & 361.0 & 46.25 & 55.75 & 92.41 & 143.50 & 99.25 \\
\hline \multicolumn{2}{|c|}{ Bani Suef 3} & 389.0 & 48.00 & 51.75 & 97.50 & 145.58 & 103.50 \\
\hline \multicolumn{2}{|c|}{ Bani Suef 4} & 466.0 & 53.25 & 54.25 & 95.92 & 144.17 & 102.50 \\
\hline \multicolumn{2}{|c|}{ Bani Suef 5} & 409.0 & 47.75 & 53.88 & 93.25 & 146.17 & 102.50 \\
\hline \multicolumn{2}{|c|}{ Sohag 3} & 457.0 & 50.50 & 51.25 & 97.08 & 145.08 & 99.42 \\
\hline \multicolumn{2}{|c|}{ Mean } & 416.4 & 49.15 & 53.38 & 95.23 & 144.90 & 101.43 \\
\hline \multicolumn{2}{|c|}{ Bani Suef 6} & 473.0 & 55.38 & 57.38 & 94.67 & 142.17 & 95.75 \\
\hline LSD0.05 & & 41.5 & 13.8 & 6.5 & 1.8 & 4.1 & 6.1 \\
\hline
\end{tabular}


Previous data of grain yield and yield components confirm the superiority of the new durum wheat cultivar over the check cultivars, i.e., Bani Suef $1,3,4,5$ and Sohag3.

These results agree with those obtained by Verma et.al. (1998) where they stated that yield components characters 1000 grains and number of tillers per plant had the highest contribution to phenotypic stability. In addition, Singh et.al. (1998) stated that the yield traits which showed good progress in improving grain yield were biomass, spikes $/ \mathrm{m}^{2}$ and kernels/ spike.

\section{5- Agronomic Characters:}

Three measurements were recorded for number of days to heading, to physiological maturity and plant height (Table 7). Days to heading ranged from 96.3 for Bani Suef 1 to 101.3 for Bani Suef 3 with an average of 99.1 for all check cultivars. Bani Suef 6 recorded 98.7 days to heading, these data were recorded over locations and presented in (Table 7). However, number of days to heading in Upper Egypt was less than that in Middle Egypt for mean of cultivars ( 95.23 vs. 102.95) and for Bani Suef 6 (94.67 vs. 102.67) Table (8), However, days to heading for Bani Suef 6 was almost similar to the mean of check cultivars in each region (102.67 vs. 102.95 in Middle Egypt and 94.67 vs. 95.23 in Upper Egypt).

Similar results were obtained for number of days to physiological maturity where recorded 149.7 days for the mean of the check cultivars and 147.7 days for Bani Suef 6 (Table 7). In addition, days to maturity for check cultivars and Bani Suef 6 in Upper Egypt were less than that in Middle Egypt (Table 8). However, days to maturity for Bani Suef 6 were similar to cultivars mean in Middle Egypt (153.17 and 154.51) and in Upper Egypt (142.17 vs. 144.90) as indicated in (Table 8).

Plant height over the two regions ranged from $104.1 \mathrm{~cm}$ for Sohag 3 to $107.5 \mathrm{~cm}$ for Bani Suef 5 indicating that selection is practiced in wheat breeding program for medium height. The new durum wheat cultivar Bani Suef 6 recoded $101.0 \mathrm{~cm}$ for plant height differing significantly from the mean of the check cultivars over locations (Table 7). Environmental conditions affected plant height where all cultivars under Upper Egypt conditions were shorter than that at Middle Egypt (Table 8). Average plant height of check cultivars in Upper Egypt $(101.43 \mathrm{~cm})$ while in Middle Egypt plant height recorded $(110.53 \mathrm{~cm})$. The new durum cultivar was the shortest cultivar in Middle Egypt $(106.25 \mathrm{~cm})$ and in Upper Egypt $(95.75 \mathrm{~cm})$.

\section{6- Rust Diseases Reaction:}

Reactions of the newly durum wheat cultivar Bani Suef 6 and five durum wheat commercial cultivars to leaf rust (LR) and stem rust (SR) of advanced yield trials at El-Nubaria Agricultural Research Station in 2006/2007 season are presented in (Table 9). These results confirm that the durum wheat cultivar Bani Suef 6 has high resistance to leaf and stem rust diseases. Moreover, the calculated average coefficient of infection (ACl) for leaf and stem rusts diseases for durum wheat cultivar Bani Suef 6 and the five commercial durum wheat cultivars at the adult stage at El-Nubaria Agricultural Research Station in 2006/2007 season (Table 10) proved that the new durum wheat cultivar Bani Suef 6 has high resistance to both leaf and steam rust diseases. 
Table (9): Reactions of the newly durum wheat Bani Suef 6 and durum wheat commercial cultivars to leaf and stem rusts in the advanced yield trials at El-Nubaria Agricultural Research Station in 2006/2007 season.

\begin{tabular}{|c|c|c|}
\hline Cultivar & Leaf Rust & Stem Rust \\
\hline Bani Suef 6 & Tr R & 0 \\
Bani Suef 1 & Tr S & $10 \mathrm{MS}$ \\
Bani Suef 3 & $40 \mathrm{~S}$ & $30 \mathrm{~S}$ \\
Bani Suef 4 & 0 & 0 \\
Bani Suef 5 & 4o S & 0 \\
Sohag 3 & Tr R & 0 \\
\hline
\end{tabular}

$\mathrm{Tr}=$ trace, $\mathrm{R}=$ resistant, $\mathrm{S}=$ susceptible, $\mathrm{MS}=$ moderately susceptible

Table (10): Mean average coefficient of infection (ACl) for Bani Suef 6 and five durum wheat commercial cultivars to leaf and stem rusts at the adult stage at El-Nubaria Agricultural Research Stations in 2006/2007 season .

\begin{tabular}{|c|c|c|}
\hline Cultivar & Leaf Rust & Stem Rust \\
\hline Bani Suef 6 & 1.00 & 0.05 \\
Bani Suef 1 & 5.00 & 8.00 \\
Bani Suef 3 & 40.00 & 30.00 \\
Bani Suef 4 & 0.05 & 0.05 \\
Bani Suef 5 & 40.00 & 0.05 \\
Sohag 3 & 1.00 & 0.05 \\
\hline
\end{tabular}

7- Distinctness, Uniformity and Stability Tests (DUS):

The last step before releasing cultivars is to promote distinctness, uniformity and Stability testing. This test was carried out by the Central Administration of Seed Certification (CASC) for two successive seasons according to the International Union for the protection of New Varieties of Plants (UPOV). Results of these tests are recorded in (Table 11) showing some morphological characteristics of the new durum wheat cultivar Bani Suef 6 .

8- Some Technological and Quality Characters:

Some technological and quality characters are presented in Table (12) and were carried out in Field Crops Technology Research Department, Food Technology Research Institute, Agricultural Research Center. The analyses included hectoliter measurements, semolina, protein and ash percentages in addition to wet and dry gluten percentages in the five durum wheat cultivars, i.e., Sohag 3, Bani Suef 1, 4, 5 and 6. Bani Suef 4 showed the highest hectoliter measurement (83.5) followed by the new cultivar Bani Suef $6(83.1)$ while the other three cultivars were less in hectoliter and ranged from 81.0 to 81.3. Data in Table (12) also showed that semolina percentage of Bani Suef 6 was $77 \%$ in second rank after Bani Suef $5(77.2 \%)$ and over the cultivars mean $(76.6 \%)$. 
Table (11): Some morphological characteristics of the new released wheat cultivar Bani Suef 6 according to the International Union for the Protection of new Varieties of Plants (UPOV)

\begin{tabular}{|c|c|c|}
\hline No & Characteristics & Description \\
\hline 1 & Pigmentation of cleoptile & Medium (3) \\
\hline 2 & Anthocyanin coloration of first leaf & Medium (5) \\
\hline 3 & Plant growth habit & Erect (1) \\
\hline 4 & Flag leaf rolling & Weak (3) \\
\hline 5 & Time of ear emergence (first spike on $50 \%$ of ears) & Medium (5) \\
\hline 6 & Glaucosity of flag leaf sheath & Strong (9) \\
\hline 7 & Glaucosity of flag leaf blade & Weak (3) \\
\hline 8 & Ear: anthocyanin pigmentation & Absent (1) \\
\hline 9 & Hairness of upper most node & Weak (3) \\
\hline 10 & Glaucosity of ear neck & Strong (7) \\
\hline 11 & Glaucosity of ear & Strong (7) \\
\hline 12 & Plant height (stem, ear and awns) & Medium (5) \\
\hline 13 & Awns distribution on the spike & Medium (4) \\
\hline 14 & Awn length compared to ear & Equal (3) \\
\hline 15 & Shape of lower glume & Rounded (3) \\
\hline 16 & Shoulder shape of glumes & Sloping (1) \\
\hline 17 & Width of glume shoulder & Narrow (3) \\
\hline 18 & Length of glume beak & Very short (1) \\
\hline 19 & Shape of glume beak & Sloping (2) \\
\hline 20 & Hairiness of glumes & Present (1) \\
\hline 21 & Thikness of parenchyma wall & Medium (5) \\
\hline 22 & Awns color & White (1) \\
\hline 23 & Ear length (ear and awns) & Medium (5) \\
\hline 24 & Ear: hair density at the lower edge of the rachis & Weak (1) \\
\hline 25 & Color of ear & White (1) \\
\hline 26 & Shape of ear & Tapering (2) \\
\hline 27 & Density of ear & Dense (7) \\
\hline 28 & Grain shape & Rounded (3) \\
\hline 29 & Length of grain brush hairs & Short (3) \\
\hline 30 & Seasonal type & Spring type (3) \\
\hline
\end{tabular}

Table (12): Some Technological and quality characters of the durum wheat cultivar Bani Suef 6 compared to other four durum wheat cultivars

\begin{tabular}{|c|c|c|c|c|c|c|c|}
\hline \multirow{2}{*}{ No. } & \multirow{2}{*}{ Cultivar } & \multirow{2}{*}{ Hectoliter } & \multirow{2}{*}{ Semolina\% } & \multirow{2}{*}{ Protein\% } & \multirow{2}{*}{ Ash \% } & \multicolumn{2}{|c|}{ Gluten\% } \\
\cline { 5 - 8 } & & & & & & Wet & Dry \\
\hline 1 & Sohag 3 & 81.3 & 76.2 & 13.6 & 2.1 & 34.0 & 11.6 \\
2 & Bani Suef 1 & 81.0 & 76.5 & 10.4 & 1.6 & 23.1 & 7.2 \\
3 & Bani Suef 4 & 83.5 & 76.0 & 12.0 & 1.7 & 25.6 & 9.4 \\
4 & Bani Suef 5 & 81.3 & 77.2 & 12.8 & 1.6 & 29.9 & 10.9 \\
5 & Bani Suef 6 & 83.1 & 77.0 & 12.9 & 1.9 & 29.6 & 10.8 \\
\hline \multicolumn{2}{r}{} \\
\hline
\end{tabular}

Protein analysis showed that Sohag 3 has the highest protein content (13.6\%) followed by the new durum cultivar Bani Suef $6(12.9 \%)$ and both cultivars surpassed the other three cultivars (10.4-12.8\%) and over the mean of all cultivars ( $12.3 \%)$. Gluten percentages of the five durum cultivars are presented in Table (12) showing that the gluten of Sohag 3 was the highest (34\%) followed by Bani Suef 5 (29.9\%) and Bani Suef 6 (29.6) while both Bani suef 1 and 4 had to lowest values of wet gluten (23.1 and 25.6\%). Similar rank was detected for dry gluten percentages where Sohag 3, Bani 
Suef 5 and Bani Suef 6 showed values of $11.6,10.9$ and $10.8 \%$, respectively , and Bani Suef 1 and 4 showed the lowest values of dry gluten ( 7.2 and 9.4\%). Elouafi et.al (1998) reported that the most important parameter for durum quality is gluten strength to obtain good quality for end products ( Pasta, borghul and couscous). Bani Suef 6 has high gluten percentage.

\section{REFERENCES}

Abdel-Aleem, M.; M. Abo-Shereef; T. Shehab El-Din .; M. Moustafa; S. Abdel Majeed; S.Sabry,Iman M.Sadek; M.Sharshar; A.Hamada; A.AboWarda; A.M. Moussa; A. Tammam; M.Moshref; E. El-Sayed; H.Ashous; M. Tawfelies;A.Mousta ;faH.Hendawy; H. El-Borhamy; A. Menshawy, A. Mousa; Wafaa A. El-Awady; A. El-Hag; R. Koumbor; S.Seleem; Nadia A.Abdel Nour; G.Sharawy; Sohir M.Hassan; A.Sewelam; S.ElSawy; S.Abdel-Dayem; A.El-Sebaei; Magda A.Abdel-Rahman; Sabah H.Abo Elela; M.Khaled; I. Amin; M.Zakaria; Manal A. Hassan; A.GadAllah; S.Hammad; M.El-Maghraby; A.Moard; Aza M.Abdel-All; A.Hagras; A.T.Moustafa; M.Mahmoud; M.Moubarak; Kadria Hegazi, A.Gomaa; O.Khalil; Enayat Ghanem;. R.Mitkees; M. El-Monofy; S.Kh.Mahmoud; N.Hanaa; M.Eid; M.Mosaad; A.Ageez; M.AbdelFattah; A.Khattab; A.Abdel-Lattif; M.Eskander; Najwa Abdel-Fattah; F.Hefnawy and W.Abdel-Samed (2008): Bani Sweef 4 : A New Durum Wheat Cultivar .J.Agric.Sci. Monsoura Univ., 33:5509-5516.

Abdel-Shafi, A.M.; A.A. Gomaa, M.G.Mosaad; M.A. Gouda; R.A.Mitkees; A.H.Bassiuni; M.M. El-Shami; S.K.Mahmoud; N.S.Hanna; A.R.Armanuous; Enayat H.Ghanem; O.S.Khalil; H.A.Ghanem; M.M.ElMenoufi; Kadreia F. Hegazi; M.M. El-Hadidi; A.M. Eissa; M.M.AbdelAleem; M.M.Hamed and S.E. El-Shereef. (1989): Bani Suef 1 and Sohag 2 Two Newly Released Durum Wheat Cultivars. Agric. Res. Rev., 67:483-489.

Bowman, D.T. (1998): Using Crop Performance Data to Select Hybrids and Varieties. J. of Prod. Agric., 11:256-259.

Eberhart, S.A. and W.A. Russell. (1966): Stability Parameters for Comparing Varieties. Crop Sci., 6:36-40.

Elouafi, I, A.Martin, L.M.Martin and M.M.Nachit (1998). Association of introgressed T.dicoccoides seed storage protein subunits with gluten strength and protein content in durum ( T.turgidum var. durum). Proceedings of the $9^{\text {th }}$ International Wheat Genetics Symposium. Saskatoon, Saskatchewan, Canada, 2-7 August, 1998.

Ghanem, Ennayat H.; A.M.Ali; M.G.Mosaad; N.S.Hanna; M.M.Abdel-Aleem; S.R.S.Sabry; S.K.Mahmoud; M.M.El-Shami; A.M.Moussa; H.M.M.Zaid; S.A.Abdel-Majeed; A.M.Tammam and Ikhlas Shafik. (1996): Grain Yield and Rusts Reaction of the New Durum Wheat Triticum turgidum L. Cultivar Bani Suef 3 .J.Agric. Sci. Mansoura Univ., 21:2781-2787. 
Ghanem, Enayat H.; O.H.S.Khalil; A.A. Gomaa; A.M.Abdel-Shafi Ali; M.G.Mosaad; R.A. Mitkees; G.S.Yousef; A.M.bdel-Ghani; S.Kh.Mahmoud ; M.M.Abdel-Aleem; N.S.Hanna; M.A.M.Eid and S.E.ElShereef. (1991): Sohag 3:A New Durum Wheat Variety for Upper Egypt. Assiut J.of Agric. Sci., 22:209-222.

Mitkees, R.A.; Enayat H. Ganem and M.G.Mosaad. (1989): Yield Stability of Some Newly Released Bread Wheat Varieties, Ann.of Agric. Sci. Moshtohor, 27:125-139.

Moustafa, M.; M.Abo-Shereef; T.Shehab- El - Din; M.Abdel-Aleem; S. Abdel Majeed; S.Sabry,Iman M.Sadek; M.Sharshar; A.Hamada; A.AboWarda; A.M. Moussa; A. Tammam; M.Moshref; E. El-Sayed; H.Ashous; M. Tawfelies; A.Moustafa ; H.Hendawy; H. El-Borhamy; A. Menshawy, A. Mousa; Wafaa A. El-Awady; A. El-Hag; R. Koumbor; S.Seleem; Nadia A.Abdel Nour and G.Sharawy (2008): Bani Sweef 5 : A New Durum Wheat Cultivar .J.Agric.Sci. Monsoura Univ., 33:55175524.

Peterson, C.J.(1997): Yield Stability of Hybrid VS. Pure Line Winter Wheat in Regional Performance Trials. Crop Sci., 37:116-120.

Sadek, Eman H.; M.M.Abdel-Aleem and M.K.Moshref. (1995): Verification of Some Improved Durum Wheat Cultivars at El-Fayoum. Egypt. J.Appl. Sci., 10:1-8.

Steel, R.G.D. and J.H.Torrie (1980):Principles and Procedures of Statistics . $2^{\text {nd }}$ Ed. Mc Graw-Hill Book Co. Inc., New York.

Singh, R.P., S. Rajaram, A. Miranda, J.Huerta-Espino and E.Autrique.1998: Comparison of two crossing and four selection schemes for yield, yield traits, and slow rusting resistance to leaf rust in wheat. In H.J.Braum et.al. (Eds.), Wheat: Prospects for Global Improvement (93-102). 1998 Kluwer Academic Publishers.

Verma, S.R , M. Yunus and S.K. Sethi (1998): Breeding for yield and quality in durum wheat. In H.J.Braum et.al. (Eds.), Wheat: Prospects for Global Improvement (61-64). 1998 Kluwer Academic Publishers. 


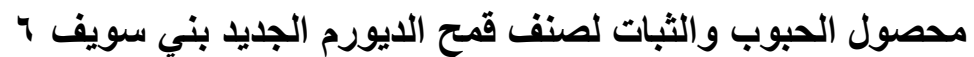

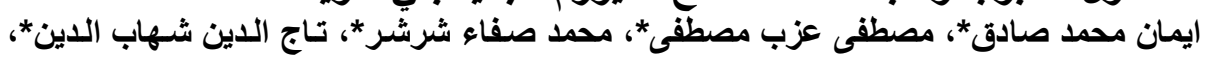

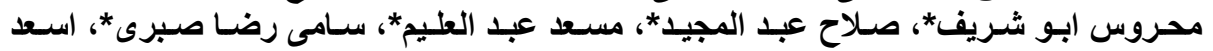

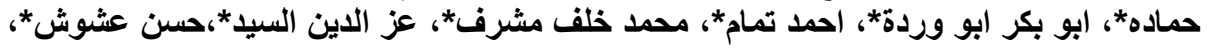

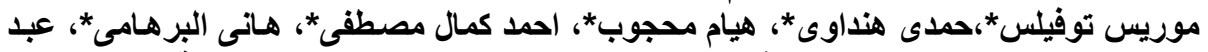

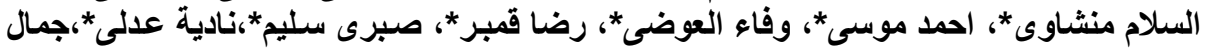

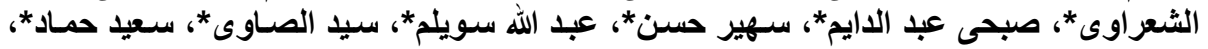

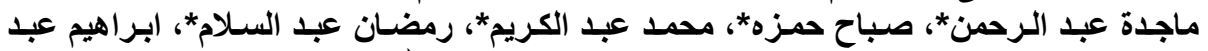

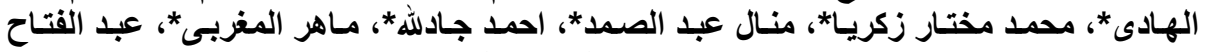

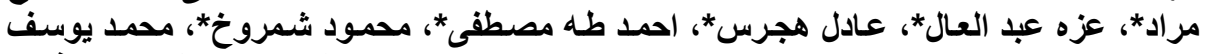

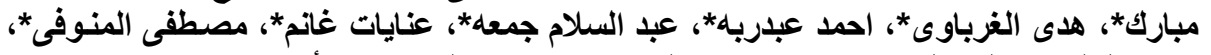

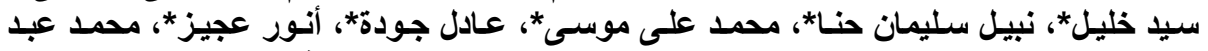

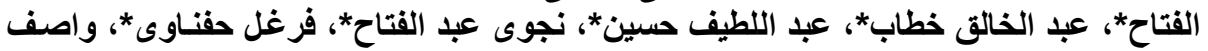

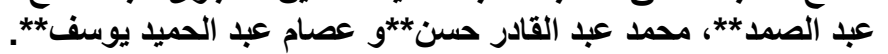

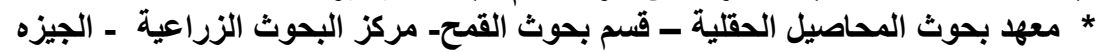

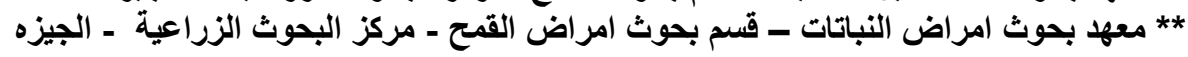

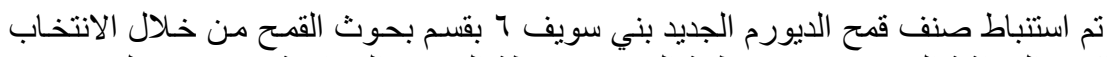

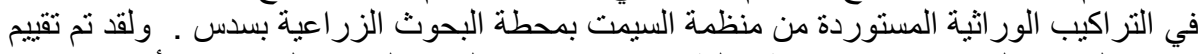

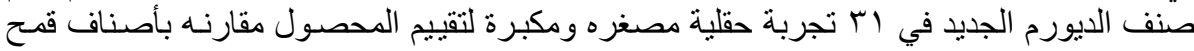

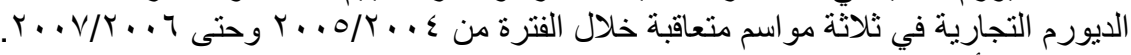

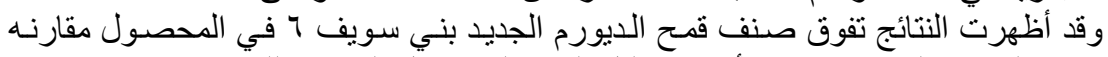

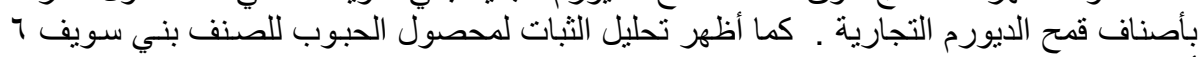

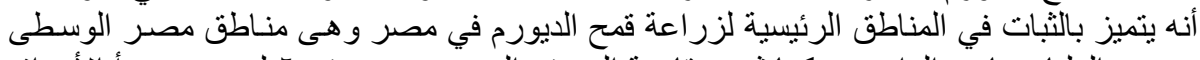

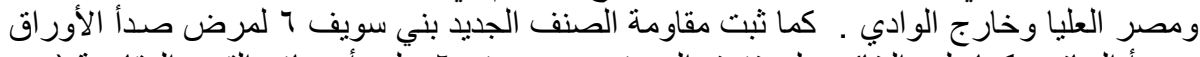

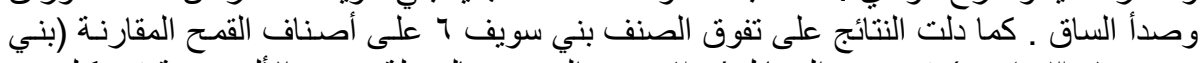

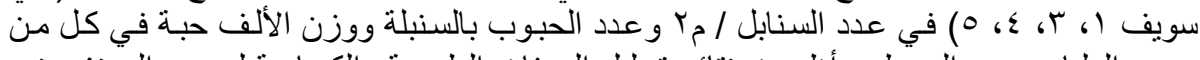

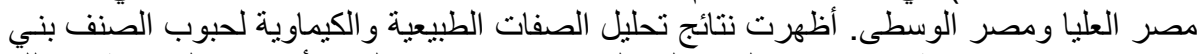

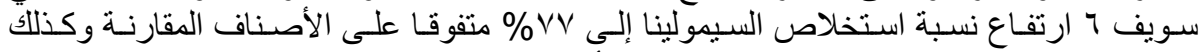

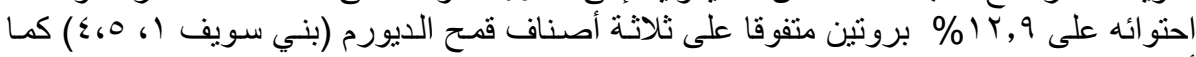

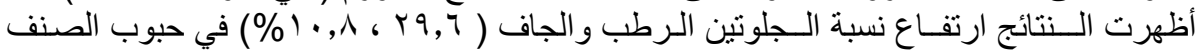
بني سويف 1 مما بدل على ارتفاع صفات الجودة وصلاحية الصنف لصناعة لكنة المكرونة.

كلية الزراعة - جامعة المنصورة

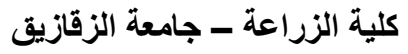

قام بتحكيم البحث

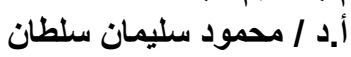

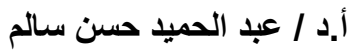

